IFN Working Paper No. 733, 2008

\title{
Gazelles as Job Creators - A Survey and Interpretation of the Evidence
}

Magnus Henrekson and Dan Johansson 


\title{
Gazelles as Job Creators - A Survey and Interpretation of the Evidence
}

\author{
Magnus Henrekson ${ }^{\dagger}$ and Dan Johansson*
}

January 22, 2009

\begin{abstract}
It is often claimed that small and young firms account for a disproportionately large share of net employment growth. We conduct a meta analysis of the empirical evidence regarding whether net employment growth rather is generated by a few rapidly growing firms so-called Gazelles - that are not necessarily small and young. Gazelles are found to be outstanding job creators. They create all or a large share of new net jobs. On average, Gazelles are younger and smaller than other firms, but it is young age more than small size that is associated with rapid growth. Gazelles exist in all industries. They seem not to be overrepresented in high-tech industries, but there is some evidence that they are overrepresented in services.
\end{abstract}

Keywords: Entrepreneurship; Firm growth; Flyers; Gazelles; High-growth firms; High-impact firms; Job creation; Rapidly growing firms.

JEL Codes: D21; L25; M13; O10; O40.

\footnotetext{
${ }^{\dagger}$ Corresponding author. Research Institute of Industrial Economics (IFN), P.O. Box 55665, SE-102 15 Stockholm, Sweden. Ph: +46-8-665 45 02. E-mail: Magnus.Henrekson@ifn.se. Personal website: www.ifn.se/mh.

\$The Ratio Institute, P.O. Box 3203, SE-103 64 Stockholm, Sweden. E-mail: dan.johansson@ratio.se. Personal website: www.ratio.se/eng/johansson
} 


\section{Introduction}

Research on the economic importance of small firms was negligible until David Birch (1979) claimed that they generated a disproportionately large share of new net jobs. ${ }^{1}$ Birch's findings have been criticized by, e.g., Brown et al. (1990); Davis et al. (1996a, 1996b) and Haltiwanger and Krizan (1999), but they sparked small business research. It is now a vigorous research field with a wide coverage, encompassing issues such as the importance of entrepreneurship, firm demography and firm dynamics for job creation and economic growth. ${ }^{2}$ Van Praag and Versloot (2008) review the empirical literature on the economic contribution of "entrepreneurial firms", i.e., small and young firms, which are found to have positive effects on employment, productivity, innovation and utility. With reference to employment Van Praag and Versloot conclude (p. 135): "Entrepreneurs create more employment than their counterparts, relative to their size. This result is unambiguous. Small and young firms are required to boost employment."3

The purpose of this article is to go one step further and survey the empirical evidence on whether, in fact, net employment growth is generated by a few rapidly growing, not necessarily small and young, firms, so-called “Gazelles”. The term was launched by Birch some twenty years ago (Landström 2005, p. 170) to denote a small group of high-growth firms that according to him generated most of the new net jobs in the economy. This stands in contrast to the few large (often publicly traded) companies, "Elephants", that according to Birch had a large employment share, but generated few new jobs, and to the vast majority of all firms that started out small, grew very little and hence contributed only marginally to employment growth. The latter firms were named "Mice". In addition, we are interested in whether Gazelles, in fact, are young and small, and whether Gazelles are overrepresented in high-tech industries. ${ }^{5}$ Much economic policy has been targeting high-tech firms since

\footnotetext{
${ }^{1}$ See also Birch $(1981,1987)$.

${ }^{2}$ See, for instance, Kirchhoff and Greene (1998) for a summary of the discussion.

${ }^{3}$ Moreover, they maintain that the methodology of the critics strengthens this conclusion (p. 135): “The results from studies following the Davis-Haltiwanger methodology, which are not reported here, only add credibility of this result."

${ }^{4}$ Gallagher and Miller (1991) instead use the terms "flyers" and "sinkers" to denote high- and low-growth firms, respectively.

${ }^{5}$ There is an extensive literature studying micro level characteristics of (high-)growth firms. In his wide-ranging survey of this literature Storey (1994) identified 35 such factors, which he classified into three categories (p. 122): i) The resources of the entrepreneur(s), e.g., motivation and education; ii) the firm, e.g., age and size; and iii) strategy, e.g., management training and market positioning. See Barringer et al. (2005) for a recent survey of this literature. The studies identified in our survey generally do not report on any other characteristics than firm age, size and industry affiliation. Still, it is interesting to include those three characteristics in the survey considering the discussion on the importance of new and small firms and considering the expectation by many on high-tech firms to generate employment (and growth).
} 
politicians have relied on high-tech firms and industries to boost economic growth and job creation. The research questions may be stated as four propositions:

Proposition 1: In a population of firms, net employment growth is generated by a small number of high-growth firms, so-called Gazelles.

Proposition 2: On average, Gazelles are younger than other firms.

Proposition 3: On average, Gazelles are smaller than other firms.

Proposition 4: Gazelles are overrepresented in high-tech industries.

In the next section we discuss the definition of Gazelles and the method used in our survey. Section 3 reports the results from the identified studies. These results are analyzed in Section 4, where we also offer our conclusions.

\section{Definitions and Method}

There is no general agreement on the definition of Gazelles. Birch (e.g., Birch et al. 1995, p. 46) defines them as "A business establishment which has achieved a minimum of $20 \%$ sales growth each year over the interval, starting from a base-year revenue of at least $\$ 100,000$." Hence, the definition is based on firms growing at least at a particular pace (e.g., that firms exhibit a certain annual growth rate or more for a certain number of years). Another way is to use a high-growth threshold and define Gazelles as the $x$ percent fastest growing firms. Recently, OECD (Ahmad 2006) proposed defining high-growth enterprises as enterprises with an average employment growth rate exceeding 20 percent p.a. over a three-year period and with 10 or more employees at the beginning of the period. They also proposed that the term Gazelle should only apply to young high-growth firms, or more specifically to enterprises less than five years old and with an average employment growth rate exceeding 20 percent p.a. over a three-year period and with 10 or more employees at the beginning of the period. Consequently, the literature is quite disparate.

Delmar et al. (2003, p. 192-197) systematize the literature on high-growth firms. Several issues are addressed showing large heterogeneity among studies:

(i) Choice of growth indicator. Employment, market share, physical output, profits and sales are by far the most commonly used.

(ii) Measurement of growth. Growth is measured in several ways, both in absolute and relative terms. Multiple or composite growth indicators and growth measures are also employed. 
(iii) The regularity of firm growth over time. Firm growth fluctuates substantially over time. The choice of time period over which growth is measured, annual growth, growth between initial and final year etc., therefore affects observed growth rates.

(iv) The process by which firms grow, i.e., organic or acquired growth. ${ }^{6}$

(v) Firm demographics. Firm size, firm age and industry affiliation have been shown empirically to have a large impact on firm growth, and therefore need to be considered.

We have also noted that two different kinds of benchmarks are used to evaluate the job contribution of Gazelles: either by comparing it to the job contribution of non-Gazelles in the investigated population or by relating it to aggregates such as total employment growth, total unemployment and the job contribution of new firms. The former is preferred in studies investigating a smaller sample of firms. Studies investigating large samples of firms, such as all firms in the private sector, also use the latter. Population refers to three types of firms: continuing firms (also called permanent firms or ongoing firms), i.e., firms existing throughout the studied period; new firms, i.e., one or several cohorts of new firms established during the studied period; or all firms, i.e., continuing firms as well as new firms established during the studied period.

Job contribution can be discussed in terms of gross job creation, i.e., total employment gains in studied units; gross job destruction, i.e., total employment losses in studied units; and net job creation, i.e., the difference between the two during the same time period (e.g., Davis and Haltiwanger 1999, Section 2.1). All identified studies measure net job creation, and when nothing else is stated this is what we refer to.

Net job creation is measured at different levels: firm, groups of firms (notably small, young and industries) and at the aggregate level. This means that net job creation may differ across levels and across groups of firms. For instance, even though total employment may decrease, certain groups of firms, e.g., new ones, may experience net job growth.

Organic growth is supposed to have a larger effect on net employment than acquired growth. Some studies investigate single establishments to deal with this alleged "problem". It is conceivable that single-establishment firms mostly grow organically. To remain a single establishment when acquiring other firms implies that acquired establishments have to be shut down and employment reallocated to the establishment of the acquiring company. This is not particularly likely; rather, one or several of the acquired establishments are likely to remain in operation.

\footnotetext{
${ }^{6}$ Organic growth is growth through new appointments in a firm, while acquired growth is growth through acquisitions and/or mergers. Organic growth and acquired growth may also be denoted internal growth and external growth, respectively. Throughout the text, the sum of organic and acquired growth will be denoted total growth.
} 
However, acquired growth is important for reallocating employment and other resources to more productive uses. Hence, Gazelles growing externally may be of crucial importance for productivity growth. Klepper and Simons (2005), for instance, show that growing industries typically experience shakeouts in which the number of firms after some time falls sharply due to exits, mergers and acquisitions. Hence, a natural pattern in the course of the evolution of an industry is that the number of firms is initially very large, but when the industry grows and matures the selection process rapidly reduces the number of firms. It therefore seems normal that Gazelles in mature industries grow through acquisitions of less efficient competitors. Klepper (2002) provides many interesting examples in this regard. The U.S. automobile industry consisted of 271 firms in 1909. This number was down 60 percent by 1923, and by the mid 1960s, only four car manufacturers remained in business. The television industry shows a similar pattern.

The studies in our survey have been identified by searching the following databases: the American Economic Association's electronic bibliography of economic literature (Econlit), Google Scholar, Journal Storage (JSTOR), Research Papers in Economics (RePEc), and Social Science Research Network (SSRN). We first searched for "Gazelle", "high-growth firm", "rapidly growing firm" and similar words and phrases in titles, abstracts, keywords, and, when possible (Econlit, JSTOR and RePEc), in the main text. ${ }^{7}$ In total, there were thousands of hits. We browsed the hits and selected the papers that investigate the employment contribution of Gazelles, or high-growth firms, relative to one or both of the identified benchmarks during a particular time period. In what follows we will use Gazelles and high-growth firms synonymously. The identified studies were then complemented by references found in the identified studies and studies we know of. We confined the survey to studies published after 1990, partly because we did not find that many studies before 1990 (earlier studies are surveyed in Storey 1994), partly because the quality of data has improved substantially in the last two decades. The primary purpose of some of the papers was not the study of the job contribution of Gazelles per se.

\footnotetext{
${ }^{7}$ The search in Google Scholar was restricted to "Gazelle" due to the unmanageable number of hits resulting from searches for the other words and phrases. We also restricted the search to results in English.
} 


\section{Results}

In total we identified 20 studies in our search, which was a much smaller number than we had expected, especially given the importance of the issue. ${ }^{8}$ The key explanation for the small number of studies is the lack of suitable data. A systematic analysis of the importance of Gazelles requires data on a large number of individual firms that can be followed over time, preferably covering all ages, sizes and industries. By their very nature such analyses are timeconsuming and costly, especially for new and small firms. Appropriate data do not even exist in many countries (Schreyer 2000; Hoffman and Junge 2006). As mentioned, academic research on these issues is also of relatively recent vintage. To begin with, research addressed fundamental issues such as whether Gibrat's Law (that a firm's growth rate is independent of its size) holds and the impact of the turnover and mobility of firms on employment and economic growth (see, e.g., Sutton 1997, Caves 1998, Lotti et al. 2003, and Audretsch et al. 2004 for surveys). Table 1 summarizes the studies in chronological order based on Delmar et al.'s (2003) systematization, and we now offer a summarizing comment and evaluation on each of them.

Table 1 about here

Birch and one of his critics, James Medoff, co-author of Brown et al. (1990), summarized what Birch and his protagonists agreed upon regarding the job contribution of small and large firms. About Gazelles they concluded (Birch and Medoff 1994) that a relatively small number of firms create a disproportionately large share of new jobs. ${ }^{9}$ During the $1988-92$ period, four percent of the firms generated 70 percent of all new jobs among ongoing firms in the U.S. These four percent accounted for about 60 percent of all new jobs in the whole economy during the same period. They were relatively small; in 1993, the average Gazelle firm employed 61 people. Gazelles were found in all industries and every industry had about the same proportion of rapidly growing firms.

Kirchhoff (1994) studies the job contribution of firms in the 1977 and 1978 cohorts of firms in the nonagricultural private sector of the U.S. economy. The analysis is based on the

\footnotetext{
${ }^{8}$ Storey (1994) reports findings from 14 studies investigating the employment contribution of rapidly growing firms and Schreyer (2000) presents seven studies on high-growth firms and employment. We count Storey's survey of 14 early studies as one study, while Schreyer's country studies are treated separately. Several studies concern Sweden, including one of the studies reported by Schreyer. As they are based on the same data set and draw similar conclusions, we treat them as one study. In total our survey therefore encompasses 20 studies.

${ }^{9}$ The section on the employment contribution of Gazelles draws on Birch et al. (1993), who base their analysis on data from Dun and Bradstreet for the 1988-92 period.
} 
Small Business Data Base (SBDB) and includes all firms established in 1977 and 1978. Multi-establishment firms and firms with more than 500 employees are excluded. ${ }^{10}$ The remaining firms (95 percent of the original population) are followed throughout 1984.

Adjustments are made to exclude firms growing rapidly as a result of mergers and acquisitions. ${ }^{11}$ Firm growth is calculated as the percentage change of employment between the beginning and end of the period. The firms are ranked according to their employment growth rate, and the uppermost decile is classified as high-growth firms. Kirchhoff finds that a small number of high-growth firms create a disproportionate share of net jobs. Four percent of the new firms produce 75 percent of employment for the entire cohort during the first six years of life. The entire 1977-78 cohort of firms made a net contribution of 3.4 million jobs in 1984 (20.6 percent of the 16.5 million net new jobs created between 1976 and 1984).

Furthermore, they amounted to four percent of total employment in 1984. However, Kirchhoff (1994, p. 188) also finds that the total job contribution of the 1977-78 cohort falls by 25 percent during their first six years of life compared to the initial number of employees at the time of their start-up, when jobs lost due to exits and job loss among survivors are deducted from employment growth among surviving firms.

Storey (1994) summarizes research on the role and functioning of small firms. Among other things he reports findings from 14 studies investigating the job contribution of rapidly growing firms (p. 113-119). ${ }^{12}$ One study concerns the U.S. and 13 studies concern the U.K. Most studies look at manufacturing, but some examine services. Based on the survey Storey (p. 119) estimates that among studied firms " ... approximately 4 percent of firms create approximately half the new jobs over a decade." In follow up studies of the characteristics of rapidly growing firms Storey $(1996,1997,1998$, 1999) investigates limited companies, or groups of companies, that in 1996 had achieved an annual compound growth in turnover of at least 30 percent in the last four years. The companies/groups of companies were not subsidiaries and also had a turnover of between 5 and 100 million pounds in 1996. The investigation was based on data from the ICC/OneSource UK Companies database. About 10

\footnotetext{
${ }^{10}$ The purpose was to try to only include truly new firms in the investigated population. Large firms and multiestablishment firms are supposed to be large firms that appear as new firms in the statistics due to ownership changes.

${ }^{11}$ Firms that exhibited employment growth of more than 400 percent any biennial period, had more than 50 employees and added more than three establishments during the same biennial period were assumed to grow through mergers and acquisitions and were therefore excluded. These firms represented less than 0.1 percent of the surviving firms in the investigated population. The adjustments are crude compared to, e.g., Davidsson and Delmar (2003), and we therefore classify Kirchhoff (1994) as studying total growth.

${ }^{12}$ The studies are: Storey (1985), Rajan and Pearson (1986), Storey et al. (1987), NIERC (1988), Reynolds and Miller (1988), Johnson (1989a, 1989b, 1991), Daly et al. (1991), Gallagher and Miller (1991), Jones (1991), North and Smallbone (1993), Smallbone et al. (1993), and Woods et al. (1993).
} 
percent of the population fulfilled the criteria, hence they were denoted "the Ten Percenters". ${ }^{3}$ Young and small firms were overrepresented among the Ten Percenters. They were found in a diverse range of industries and the sectoral variations in the concentration of Ten Percenters were moderate. Storey does not, however, compare the job contribution of the Ten Percenters to that of other firms. Consequently, we do not include these reports in Table 1.

Birch et al. (1995) study the job contribution of different types of firms. They use Dun and Bradstreet data for 1990-94 covering all size classes and industries in the U.S. Despite the fact that Gazelles only represent three percent of the firm population, Birch et al. (1995) report that they account for all employment growth between 1990 and 1994. ${ }^{14}$ In 1990, 82 percent of them employed fewer than 19 people and only 3.6 percent employed at least 100 people. However, the 3.6 percent of Gazelles that start from a base employment of at least 100 are, on the other hand, "spectacular" job creators. They account for more than half (53 percent) of the jobs created by Gazelles. Birch et al. (1995, p. 8) call them "Superstars". Some of them were already Fortune 500 companies while others were heading rapidly in that direction. ${ }^{15}$ Gazelles are found in all industries. In fact, the share of high-growth firms is about the same across sectors. Only 1.8 percent of all Gazelles are in high-tech industries.

Picot and Dupuy (1998) analyze the job contribution by size class in Canadian firms. ${ }^{16}$ They employ a longitudinal data set covering all firms in the business sector for the years 1978-92 (annual data). Irrespective of the measures of growth, small firms generate a disproportionate share of net jobs in the whole economy. The result is largely due to new firms. Excluding firm entry, the disparity between the small and large firm sector disappears. The job contribution is very unevenly distributed among growing firms. It is heavily concentrated to a few rapidly growing firms. Among continuing small firms (studied for the 1983-86 period), 5 percent accounted for 43 percent of jobs gained. High-growth firms are found in all size classes and a number of large firms create a significant share of new employment. The correlation of a firm's growth is low between adjacent periods, suggesting that past growth is a poor predictor of future growth.

Autio et al. (2000) study the impact of Finnish Gazelles. Gazelles are defined as independent single-establishments increasing their sales by at least 50 percent during three

\footnotetext{
${ }^{13}$ Parker et al. (2005) use the same data to analyze why Gibrat's Law does not hold for Gazelles by testing hypotheses derived from dynamic management theories.

${ }^{14}$ Gazelles generated 5.0 million net jobs, while total net job growth in the whole economy only amounted to 4.2 million.

${ }^{15}$ Birch et al. (1995) do not report the age of the Gazelles. However, they conclude that old and large firms were major job losers (large Gazelles being notable exceptions) and that young and small firms do better. They also write that this is a common pattern during recessions.

${ }^{16}$ Data on firm age and industry are not reported.
} 
consecutive years from 1994 to 1997. To qualify as a Gazelle a firm also requires a turnover of at least FIM 1 million by the end of the period. ${ }^{17}$ All establishments meeting the Gazelle criteria are included. They find Gazelles to be important job contributors, especially a few Gazelles showing an "ultra-rapid" growth. Altogether the Gazelles increased their employment by more than 400 percent during the studied period. Most Gazelles were found in trade or in services. High-technology firms were not over-represented among the Gazelles. No information is provided on the age of the Gazelles and the effect of firm size is not discussed.

Brüderl and Preisendörfer (2000) study the employment effects and growth of new firms in Bavaria, Germany. The data are part of the Munich Founder Study. The analysis is based on a stratified sample of firms established in 1985 and 1986, and interviews are made to examine whether there are any factors predisposing a firm to grow rapidly. Agricultural businesses, architects, crafts, lawyers and physicians, making up about 20 percent of all newcomers, were not covered by the data and therefore excluded. To qualify as rapidly growing firms had to fulfill three criteria: survival until 1990, growth by at least 100 percent by the end of the period and an employment increase by at least 5 employees during the same period. About one fourth of the initial employment in the studied firms was lost due to closures. Job losses due to contraction of firms were small. The expansion of surviving firms more than compensated for the losses and total employment increased by 20 percent during the period. Fast-growing firms, constituting about 4 percent of the initial sample and about 6.5 percent of the surviving firms, were the main job contributors. By the end of the period, they had expanded their employment at the year of establishment by close to 400 percent. Their contribution to aggregate employment growth in the whole population of studied firms exceeded 150 percent.

Schreyer (2000) presents the result from six OECD country studies (France, Germany, Italy, the Netherlands, Spain and Sweden) and from Quebec in Canada. ${ }^{18}$ The data are not fully comparable and the applied methodology varies somewhat across countries. All studies investigate permanent firms employing 20 or more (10 in Spain and no threshold in Germany) people at the beginning (end in the Netherlands and in Sweden). They investigate different time periods; see Table 1. All studies include manufacturing. Italy, Spain, Germany and Sweden also include services. Firm growth is measured as a composite index. ${ }^{19}$ Gazelles are

\footnotetext{
${ }^{17}$ In 1997 the exchange rates were roughly FIM/EURO = 5.9 and FIM/USD = 5.2.

${ }^{18}$ See also OECD (2002).

${ }^{19}$ The composite index is calculated as $m=\left(x_{\mathrm{t} 1}-x_{\mathrm{t} 0}\right) \times\left(x_{\mathrm{t} 1} / \mathrm{x}_{\mathrm{t} 0}\right)$, where $x_{\mathrm{t} 1}$ and $x_{\mathrm{t} 0}$ denote employment size by the end and the beginning of the period. Germany is the exception; for German firms growth is calculated as logarithmic AARG (average annual rate of growth).
} 
defined as the five (Quebec, Italy, the Netherlands and Sweden) or 10 (France, Spain and Germany) percent fastest growing firms in a reference population. The Netherlands, Spain and Sweden define the reference population as all ongoing firms. For France, Quebec and Germany the reference population is defined as all ongoing and growing firms, while in Italy it is defined as all firms in manufacturing having between 20 and 499 employees. Nevertheless, Schreyer (2000) maintains that a number of general findings emerge: Highgrowth firms account for a disproportionately large part of net job creation. Among highgrowth firms, job creation rates of small firms exceed those of large ones. Large high-growth firms are substantial job creators in absolute terms. However, their rapid growth seems to be due to mergers and acquisitions. High-growth firms tend to be younger than the average firm, and high-growth firms are found in all industries and in all regions of the countries examined.

The Swedish study in Schreyer was carried out by Per Davidsson and Frédéric Delmar, who also conducted three of the other studies identified in our survey: Davidsson and Delmar (2003, 2006) and Delmar et al. (2003). These three studies basically use the same data and draw the same conclusions. ${ }^{20}$ We therefore comment upon them jointly. The data include all commercially active firms in the non-government sector, independent as well as dependent (i.e., subsidiaries and branches), with 20 or more employees in November 1996. The data cover the period 1987-96. The studies investigate the job contribution of high-growth firms in Sweden relating it to: the job contribution of non-high-growth firms, total job creation in the economy, the job contribution of new firms established in 1996 and total unemployment in the Swedish economy. ${ }^{21}$ They discuss the employment contribution of high-growth firms distributed over industries, size classes, firm age and type of governance (independent firm or belonging to a company group). High-growth firms are defined as the ten percent of firms exhibiting the highest average annual increase in absolute employment among all firms in the population, i.e., both continuing and new firms. ${ }^{22}$ The Swedish studies and a new study on Finnish data (Deschryvere 2008) differ from the other studies in our survey in one important respect: They separate organic from acquired growth.

In contrast to other studies, the job contribution of Gazelles is reported to be modest in the Swedish studies. This conclusion is based on relating the contribution of Gazelles to total job growth in the economy, to the job contribution of new firms established in 1996 and to total

\footnotetext{
${ }^{20}$ As does the Swedish study in Schreyer (2000).

${ }^{21}$ They also specifically relate to the claim that "a small group of rapidly growing firms account for almost all employment growth in the economy."

${ }^{22}$ Delmar et al. (2003) apply 19 measures of firm growth, e.g., organic growth, acquired growth and relative and absolute growth in employment and sales, respectively.
} 
unemployment. However, there are some special circumstances affecting the results concerning the comparison with to the total job growth and to total unemployment. Foremost, during the time period Sweden went through the worst depression in modern times, showing negative GDP growth for three consecutive years (1991-93). In fact, aggregate employment decreased during the studied time period. As Davidsson and Delmar point out this sharply influences their results. Also, the large government sector in Sweden, accounting for roughly one third of total employment, lowers the potential job contribution of private firms. ${ }^{23}$ This is particularly true for the service sector, from which private entrepreneurs were largely barred (see, e.g., Henrekson 2005 and Johansson 2007 for a discussion).

As regards the comparison with the employment contribution of new firms, Davidsson and Delmar (2003) report new firms to generate approximately 40,000 new jobs and highgrowth firms to generate 45,000 new jobs in $1996 .{ }^{24}$ The result is in line with Halabisky et al. (2006), who report the net employment effect of churning (job gains in entries less job losses in exits) to exceed that of high-growth firms. The results may rather reflect the importance of new firm formation than the modest effect of high-growth firms. ${ }^{25}$

Davidsson and Delmar (2003) and Delmar et al. (2003) do not base their conclusion about the modest contribution on a comparison with the non-high-growth firms in their population. ${ }^{26}$ Relating the job contribution of Gazelles to that of other firms in the population examined, it is clear that high-growth firms are major job contributors; see Table 2. While the other firms lost more than 250,000 employees during the studied period, high-growth firms expanded by more than 180,000 employees (organic and acquired growth). Even if the analysis is restricted to organic growth, high-growth firms make a substantial job contribution. We therefore modify Davidsson and Delmar's inference and conclude that highgrowth firms are most important in the studied population. ${ }^{27}$ This is in accordance with the findings in the other studies reaching the conclusion that Gazelles are important. ${ }^{28}$

\footnotetext{
${ }^{23}$ The investigated firm population also only covers about 60 percent of private employment (Davidsson and Delmar 2006).

${ }^{24}$ The new firms in 1996 are separate from the population including the Gazelles.

${ }^{25}$ There are numerous studies documenting the importance of new firm formation. Compare, for instance, the previously mentioned result by Kirchhoff (1994) who reports the 1977-78 cohorts of firms to account for four percent of total U.S. employment in 1984.

${ }^{26}$ Davidsson and Delmar (2006) relate to the non-growth firms and conclude that high-growth firms contribute significantly to net employment growth, although insufficiently to single-handedly solve the severe aggregate underemployment problem in Sweden in the mid 1990s.

${ }^{27}$ The performance differences between high-growth and non high-growth firms were even more pronounced in the depression years. The performance of high-growth firms was only marginally affected by the depression, while the rest of the economy suffered massive job losses.

${ }^{28}$ The seemingly paradoxical result that Gazelles are important net job creators compared to other private firms, but not markedly so when related to aggregate employment growth, is consistent with the Swedish institutional
} 
Table 2 Employment growth broken down by organic and acquired employment, 1987-96.

\begin{tabular}{lrrr}
\hline Growth by group & Firms; 10\% highest growth & Firms; other & Firms; total \\
\hline Total employment growth & 185,264 & $-251,633$ & $-66,369$ \\
Organic employment & 59,626 & $-325,322$ & $-265,696$ \\
growth & & &
\end{tabular}

Source: Davidsson and Delmar (2003, Table 2.2, p. 13).

Note: This table just reproduces the parts of Davidsson and Delmar's table that are relevant for our survey.

Firm size, firm age and industry affiliation exhibit a significant relationship with firm growth. Studying total growth, large firms are overrepresented among high-growth firms. According to Davidsson and Delmar $(2003,2006)$ this is expected due to the choice of studying absolute employment growth. Firm age has a negative influence on rapid growth. While high-growth firms exist in all industries, service industries are overrepresented: the professional service sector has twice as a high representation among the top 10 percent firms compared to its share of the entire population.

Studying organic growth, the result for size is altered, while the results for age and industry are strengthened. Smaller firms grow organically to a greater extent, while larger firms mainly grow through mergers and acquisitions. High-growth company groups even exhibit negative growth in organic terms. Hence, independent firms loom larger when the focus is on organic growth. In high-growth firms younger than five years, 80 percent or more of employment growth is organic, while the corresponding share for high-growth firms older than 10 years is a mere 16 percent. High-growth firms are overrepresented in young and growing industries with a large inflow of new firms, especially in knowledge-intensive business-to-business services, education and health care. About two thirds of the high-growth firms were established during the period covered by the analysis.

Delmar et al. (2003, p. 210-211) conclude: "In relation to previous research, these results largely support a view that organic growth is more associated with young and small firms, and that acquisition growth is more common among larger and older firms, and firms in stagnant or low-tech industries." Moreover, they conclude that age, rather than size, determines rapid growth and, hence, that new firm formation and early growth of new firms are crucial for net employment growth, particularly in young and growing industries. Davidsson and Delmar

setup. For most of the post-war period Swedish economic policy disfavored entrepreneurship and private wealth formation (e.g., Henrekson and Johansson 1999; Henrekson and Jakobsson 2005). Hence, at the same time as Gazelles may be important job creators compared to other private firms, economic policy may dampen the growth of Gazelles and other private firms so that their contribution to total employment becomes modest (e.g., Davidsson and Henrekson 2002). 
(2006) write that the results indicate that renewal leads to organic growth as well as growth in the whole economy. ${ }^{29}$

The purpose of Littunen and Tohmo (2003) is to investigate the factors involved in the start-up and first years of existence of firms that also experience rapid growth, e.g., characteristics and motives of the founding entrepreneur. They study a sample of Finnish metal-based manufacturing and business service firms founded in 1990. The firms are followed until 1997. To be classified as high-growth, a firm has to more than double its turnover in real terms over the 1990-97 period. In addition, its turnover has to be at least FIM 500,000 by 1997 . In 1997, overall employment in the sample studied had increased. Employment of non-high-growth firms was reduced. Employment of high-growth firms increased not just to offset the decrease, but also to increase total employment (Table IV, $p$. 196). It is noteworthy that Finland was in a deep recession when the study was conducted. ${ }^{30}$

Fritsch and Weyh (2006) study the employment trajectories in the 18 cohorts of start-ups founded from 1984 to 2002 in West Germany. The data are taken from the German Social Insurance Statistics. They cover all private sector industries and include start-ups with at least one employee. Start-ups that have more than 20 employees in the initial year are excluded, a main motivation advanced for this decision is to avoid including firms that are not genuinely new but a result of the reorganization of large firms. The median start-up only has one employee. Employment growth is measured in absolute terms. A particular definition of Gazelles or high-growth firms is not used, but employment shares of the largest 1, 5, 10 and 25 percent firms in different cohorts are reported. Fritsch and Weyh (2006) observe that the cohorts have a propensity to start by expanding employment. However, employment growth ceases quite soon; employment in a cohort stagnates or declines after one or two years. On average, total employment in a cohort has fallen below its initial level after eight years. This has two causes. First, mortality of individual new firms is high, and after 10 years just about half of manufacturing firms in a cohort survive. The corresponding figure in services is even lower, about one third. Second, most surviving firms do not grow. ${ }^{31}$ Just a few firms do. On the other hand, these firms generate a significant number of new jobs. The authors conclude that a small fraction of firms dominate job creation. By the end of the period one percent of the firms accounted for about 44 percent and five percent of the firms accounted for close to

\footnotetext{
${ }^{29}$ This resembles, for instance, the point made by Storey (1995) that the essential issue is how many small firms grow into large firms when criticizing Harrisson's (1994) view that the importance of small firms is exaggerated. See also Acs (1995).

${ }^{30}$ The impact of firm size is not discussed in the study.

${ }^{31}$ On average, the median size of surviving firms is four employees in manufacturing and three employees in services at the end of the period.
} 
three quarters of the jobs in the initial cohort. In 2002, employment in the 18 studied cohorts made up about one fourth of total employment in the private sector industries. Fritsch and Weyh (2006) also test Gibrat's Law for all studied cohorts for all years. Gibrat's Law is rejected for all cohorts and for all years.

Halabisky et al. (2006) study the job contribution of hyper- and strong-growth firms in Canada from 1985 to 1999. Data from the Longitudinal Employment Analysis Program (LEAP) and the Small Area File (SAF) are used. The data include all firms with employees, except in health, education and government. Hence, firms with zero employees are excluded. The study focuses on firms in full-year operation in 1985 and still in business in 1989, i.e., continuing firms. A hyper-growth firm is defined as a firm growing by 150 percent in terms of employment in the four-year period 1985 and 1989, and a strong-growth firm is growing 50-150 percent in the same period. The job contribution of hyper- and strong-growth firms and other types of firms is related to the overall job creation in the private sector and to the net employment effect of churning (job gains in entries less job losses in exits). The job contribution in different phases of the business cycle is of particular interest. The hyper- and strong-growth firms, representing seven percent of the population, accounted for 56 percent of net job growth in the private sector (nearly one million out of 1.8 million new jobs). Small firms (less than 100 employees) dominated among rapid growers. ${ }^{32}$ High-growth firms were resistant to recession and hardly lost any jobs as a group (employment stayed roughly constant) in the downturn that occurred during the period. In particular, high-growth firms contribute tremendously to job creation in provinces experiencing weak overall employment performance. Rapidly growing firms are found in all industries, and high-tech is not overrepresented. If anything, services are overrepresented. The net effect of churning over the period resulted in 1.3 million new jobs. ${ }^{33}$ Hence, entry is found to be of crucial importance for total job growth.

Acs and Mueller (2008) study the employment effect of business dynamics in a regional context. They combine data from the Longitudinal Establishment and Enterprise Microdata (LEEM) with data from the Current Employment Statistics (CES) survey. Every U.S. private sector (non-farm) business with employment is covered. The analysis is carried out for 320 U.S. Metropolitan Statistical Areas (MSAs) and covers the 1990-2003 period. Growth is

\footnotetext{
${ }^{32}$ The study does not report any results pertaining to firm age. Hence, it is not possible to investigate the finding in several other studies that this is largely driven by firm age.

${ }^{33}$ Hence, hyper- and strong-growth firms together with the net effect of churning added about 2.3 million net jobs. Slow growth firms added about another 380,000 net jobs, while declining (not exiting firms) lost 850,000 jobs. Altogether, the private sector grew by 1.8 million jobs.
} 
measured as percentage change of employment in the MSAs over a three-year period. The start-up rates in the MSAs are used as a measure of business dynamics. The start-up rates in one year and each of the preceding six years are regressed on growth in order to analyze the long term effect of business dynamics on employment. New firms are differentiated according to their size, measured as the number of employees in the year of entry. Gazelles are defined as new firms having 20-499 employees in the year of establishment and experiencing persistent employment growth over time. New firms have a strong effect on employment in the year of entry. The effect fades after six years. Only Gazelles located in large diversified Metropolitan Areas exhibit pronounced long-term job effects.

Acs et al. (2008) revisit some of the earlier conclusions of Birch's work on rapidly growing firms with new and better data: The Business Information Tracking System (BITS) and the Corporate Research Board's American Corporate Statistical Library (ACSL). Rapidly growing firms are referred to as high-impact firms, which are defined as enterprises (p. 4): "with sales at least doubling over the most recent 4-year period and which have an employment growth quantifier of two or greater over the same period". The employment growth quantifier is, in turn, defined as the product of absolute and relative change in employment over a four-year period. They look at four sets of questions: high-impact firms compared to non-high-impact firms, the location by industry and region of high-impact firms and what type of firms high impact firms are before and after they become high-impact firms. The data include all firms in all industries and cover the period from 1994 to 2006. The main period of analysis of the high-impact firms is 1998-2002. The 1994 to 1998 period is used to study the nature of high-impact firms before they become high-impact firms and the 2002 to 2006 period is used to study high-impact firms after they have become high-impact firms. High-impact firms exist in all industries and regions accounting for 2-3 percent of all firms depending on industry and region. High-tech industries are not overrepresented. They are of all sizes and create almost all employment growth in the whole economy. High-impact firms with less than 500 employees and high-impact firms with more than 500 employees create about half of the new jobs each. The rate of high-impact firms that continues as high-impact firms is double in the 500+ size class compared to smaller high impact firms. These are called super Gazelles. Close to all job losses are due to non-high-impact firms with more than 500 employees. High-impact firms are not young; their average age is around 25 years. This is, however, considerably less than the average age of non-high-impact firms. A conclusion is that a diversified economy enhances the creation of high-impact firms since such firms can be found in all industries and since the growth of industries shift over time. 
Deschryvere (2008) studies the job contribution of high-growth firms in Finland. He applies the definition proposed by OECD (2006) and defines high-growth firms as firms with an average employment growth greater than 20 percent p.a. over a three-year period, and with 10 or more employees at the beginning of the period. The investigated period covers the three-year period 2003-06 and the analysis is based on the firm and establishment data from the Finnish Business Register. Continuing firms are analyzed. According to the definition, high-growth firms make up 5.4 percent of the total stock of firms with more than 10 employees, corresponding to 750 firms. When the definition is based on organic growth the number of high growth firms is reduced to 642 , corresponding to 4.6 percent of the population. Most high-growth firms start out small but medium-sized rapidly growing firms create most jobs. There is a negative relationship between initial firm size and organic growth. Firm age is not reported. During the studied period the Gazelles in total added 62,000 net jobs to the economy, whereof 65 percent (about 40,000 in absolute terms) through organic growth. High-growth firms generated about 90 percent of all net jobs created in the Finnish economy during the studied period. High-growth firms are represented in most industries.

\section{Discussion and Conclusions}

It is apparent from our survey that the studies differ in their definitions of Gazelles, measures of growth and time periods. They also differ regarding industries, firm sizes, firm ages, methods used and geographical coverage. Sometimes this is a drawback since comparability may be impaired. However, in this case the large variation should be seen as an advantage, since the results regarding the importance of Gazelles turn out to be quite robust. Regardless of definition, method, time period etc. some findings emerge.

Proposition 1 is supported. A few rapidly growing firms generate a disproportionately large share of all new net jobs compared to non high-growth firms. This is a clear-cut result. All studies find Gazelles to generate a large share, all or more than all net jobs (in the case where employment shrinks in non-Gazelle firms taken as a whole). It is noteworthy that this is particularly pronounced in recessions when Gazelles continue to grow.

Proposition 2 is also supported. The results regarding age are unambiguous. All studies reporting on age find that Gazelles tend to be younger on average. Super Gazelles are also relatively young.

As regards proposition 3 the results are ambiguous. Gazelles can be of all sizes, small firms are overrepresented but larger Gazelle firms are important job contributors in absolute terms, in particular a small sub-group of so-called Superstars or super Gazelles. These are 
both large firms and major net job creators. It appears that newness is a more important factor than small size.

Proposition 4 is not supported There is no evidence that Gazelles are overrepresented in high-tech. Gazelles exist in all industries. If anything, they appear to be overrepresented in services.

All studies but the ones based on Swedish data and the new Finnish study investigate total growth. Since organic growth is supposed to generate new employment to a larger extent than acquired growth, the conclusions may be altered when organic growth is studied. However, the Swedish and Finnish studies show that the conclusions are similar irrespective of whether organic or total growth is studied. Rather, the conclusions are more pronounced when organic growth is the object of study. It is also noteworthy that the growth of young and small firms is more organic compared to large and old firms. Hence, they make a larger contribution to net employment growth. We have little reason to surmise that the pattern in other similar countries would be different. Moreover, the studies focusing on single establishments - where acquired growth is likely to be insignificant - report similar results. ${ }^{34}$

This survey of existing studies clearly shows that a small number of high-growth firms are particularly important for net job creation. Moreover, it is clear that Gazelles more often than not are young firms. ${ }^{35}$ Nevertheless, this conclusion still rests on a fairly small number of studies. Additional studies would therefore be of great value. There are a number of ancillary aspects that could be dealt with concurrently such as the importance of spatial localization (e.g., Stam 2005) and whether other performance measures such as the growth in sales lead to similar conclusions (e.g., Moreno and Casillas 2007). One should also use alternative econometric approaches, such as quantile regression techniques, to examine whether more accurate estimates can be obtained (e.g., Coad 2007). Yet another interesting expansion would be to study the economic significance of firms showing exceptional growth rates in more detail (e.g., Markman and Gartner 2002).

The results also provide additional perspectives on two discussions raised in several papers. The first discussion concerns the question whether it is the entry of many new firms or the rapid growth of a few firms that generate employment growth, the so-called "Mice vs. Gazelles debate" (cf. Davidsson and Delmar 2003, 2006). Our survey suggests that the two views are complementary. The studies in this survey indicate that employment in new firms

\footnotetext{
${ }^{34}$ Even though acquired growth is supposed to have less effect on new employment it may have a strong effect on productivity growth, and therefore be of great economic importance.

${ }^{35}$ This is in line with, for instance, Haltiwanger (2006), who reports a negative relation between firm age and firm growth and that young firms exhibit rapid net growth and high volatility.
} 
are crucial for total employment growth and seems to be at least of equal importance as the net job contribution of continuing (Gazelle) firms. The positive employment effect of new firm cohorts tends to decline over time. Thus, continuous entry of new firms is required to achieve net job creation. ${ }^{36}$ Parker et al. (2005) also report that only a small subset of the Gazelles show sustained growth. Hence, it seems plausible that a high inflow of new firms increases the likelihood to generate young Gazelles (with sustained growth), which tend to have a larger impact on aggregate employment than older Gazelles, since the former are more likely to grow organically.

The second discussion concerns the assertion that small businesses contribute disproportionately to job creation. The critics of this claim have pointed to the quality of data, the narrow emphasis on net job contribution, and the disregard of gross job flows and regression-to-the mean effects (e.g., Haltiwanger and Krizan 1999). ${ }^{37}$ An often overlooked part of the critique, and in our opinion perhaps the most important one, is that net employment growth has to be viewed in a broader perspective of creative destruction, where net employment growth entails considerable churning and restructuring in a dynamic process of firm entry, expansion, decline and exit. ${ }^{38}$ Hence, gross job flows are critical for net job growth, since they are part of, and a prerequisite for, the discovery procedure of new business opportunities that create jobs in the long run. It may therefore be misleading to narrowly focus on a particular piece of this process and claim that it alone contributes a disproportionately large share of net employment growth.

This is not to deny that some firms are more important than others in the process of creative destruction, in the same sense that some entrepreneurs are more important than others; cf. Acs' (2008) discussion of high-impact entrepreneurship. However, a prerequisite for the growth of these firms is also that the process of creative destruction functions so that efficient new and expanding firms can attract resources from inefficient firms, resources that are released through contraction and exits. Without this dynamic reallocation the growth of firms will be hampered, irrespective of their inherent growth potential. ${ }^{39}$ The policy

\footnotetext{
${ }^{36}$ Fritsch and Mueller (2004) find that the employment effect from new entry follows a "wave pattern". Initially employment increases due to the direct effect on employment from entering firms, thereafter it declines as a result of exits of failed entrants and crowding out of incumbent firms with lower productivity than the successful newcomers. Finally, positive supply-side effects increase employment in the long run. See Fritsch (2008) for a summary of the empirical evidence and a discussion. Fritsch (2008, p. 12) argues that the positive supply side effects only show up if economic policy supports a "selection of the fittest" scenario. This means that policy distorting the market selection process should be avoided.

${ }^{37}$ See also Davidsson (2004) for an elaboration on numerous pertinent methodological issues.

${ }^{38}$ See Johansson (2005) for a recent example.

${ }^{39} \mathrm{Cf}$. Davidsson and Delmar (2006) who argue that economic policy should be focused on renewal in the form of entry of new firms, particularly in young and expanding industries.
} 
implications are in line with the OECD's (2007) recent assessment that the evidence of favorable policy impact is more clear-cut for macro/institutional policies than for various types of targeted micro policies. ${ }^{40}$

Further support of our conclusions that different views are complementary in the two discussions, is given by the increasing evidence that turbulence in itself, i.e., the entry and exit of firms, boosts job creation (e.g., Bartelsman et al. 2004, 2005; Brown et al. 2006; Birch 2006; Fogel et al. 2008; Caballero 2007). Turbulence is a natural effect of an accelerated search for new business opportunities and a rapid reallocation of resources from unsuccessful to successful firms, and when an industry evolves and becomes more mature it is natural that the market selection process reduces the number of firms, in some cases to a very small number (Klepper 2002). This implies that an employment-enhancing policy should aim at lowering barriers to new firm entry and firm exit to support an experimental process increasing the number of trials (new firms) from which potential Gazelles can be "recruited", and not hindering the closure of failures.

\section{Acknowledgements}

We thank Niclas Berggren, Carl Magnus Bjuggren, James Chrisman, Per Davidsson, Simon Parker, Mikael Stenkula, Michael Wyrwich, participants at a Ratio seminar, and participants at a seminar at the $12^{\text {th }}$ International Schumpeter Conference in Rio de Janeiro for useful comments and suggestions. Henrekson acknowledges financial support from the Gustaf Douglas Research Program on Entrepreneurship at the Research Institute of Industrial Economics, and from Catarina and Sven Hagströmers Stiftelse. Johansson acknowledges financial support from Sparbanksstiftelsen Alfa.

\section{References}

Acs, Z.J. (1995). Symposium on Harrison's ‘Lean and Mean’. Small Business Economics 7(5), 333335.

Acs, Z.J. (2008). Foundations of High Impact Entrepreneurship. Foundations and Trends in Entrepreneurship 4(6), 535-620.

Acs, Z.J. \& Mueller, P. (2008). Employment Effects of Business Dynamics: Mice, Gazelles and Elephants. Small Business Economics 30(1), 85-100.

Acs, Z.J., Parsons, W. \& Tracy, S. (2008). High Impact Firms: Gazelles Revisited. An Office of Advocacy Working Paper, U.S. Small Business Administration.

Ahmad, N. (2006). A Proposed Framework for Business Demographic Statistics. OECD Statistics Working Paper Series, STD/DOC(2006)3, Paris.

\footnotetext{
${ }^{40}$ For a thorough discussion of key institutions and macro policies likely to foster Gazelles, see Henrekson and Johansson (2009).
} 
Audretsch, D.B., Klomp, L., Santarelli, E. \& Thurik, A.R. (2004). Gibrat's Law: Are the Services Different? Review of Industrial Organization, 24(3), 301-324.

Autio, E., Arenius, P. \& Wallenius, H. (2000). Economic Impact of Gazelle Firms in Finland. Working Papers Series 2000:3, Helsinki University of Technology, Institute of Strategy and International Business, Helsinki.

Barringer, B.R., Jones, F.F. \& Neubaum, D.O. (2005). A Quantitative Content Analysis of the Characteristics of Rapid-growth Firms and their Founders. Journal of Business Venturing 20(5), 663-687.

Bartelsman, E.J., Haltiwanger, J. \& Scarpetta, S. (2004). Microeconomic Evidence of Creative Destruction in Industrial and Developing Countries. The World Bank, Policy Research Working Paper Series No. 3464.

Bartelsman, E.J., Scarpetta, S. \& Schivardi, F. (2005). Comporative Analysis of Firm Demographics and Survival: Evidence from Micro-level Sources in OECD Countries. Industrial and Corporate Change, 14(3), 365-391.

Birch, D.L. (1979). The Job Generation Process. MIT Program on Neighborhood and Regional Change, Massachusetts Institute of Technology, Cambridge, MA.

Birch, D.L. (1981). Who Creates Jobs? The Public Interest, 65(Fall), 3-14.

Birch, D.L. (1987). Job Creation in America. New York: Free Press.

Birch, D.L. (2006). What Have We Learned? Foundations and Trends in Entrepreneurship, 2(3), 197202.

Birch, D.L., Haggerty, A. \& Parsons, W. (1993). Who's Creating Jobs? Boston: Cognetics Inc.

Birch, D.L., Haggerty, A. \& Parsons, W. (1995). Who's Creating Jobs? Boston: Cognetics Inc.

Birch, D.L. \& Medoff, J. (1994). Gazelles. In L.C. Solmon \& A.R. Levenson, (Eds.), Labor Markets, Employment Policy and Job Creation (pp. 159-167). Boulder, CO and London: Westview Press.

Brown, C., Haltiwanger, J. \& Lane, J. (2006). Economic Turbulence: Is a Volatile Economy Good for America? Chicago and London: University of Chicago Press.

Brown, C., Hamilton, J. \& Medoff, J. (1990). Employers Large and Small. Cambridge, MA: Harvard University Press.

Brüderl, J. \& Preisendörfer, P. (2000). Fast-growing Businesses: Empirical Evidence from a German Study. International Journal of Sociology, 30(3), 45-70.

Caballero, R. (2007). Specificity and the Macroeconomics of Restructuring. Cambridge, MA: MIT Press.

Caves, R. (1998). Industrial Organization and New Findings on the Turnover and Mobility of Firms. Journal of Economic Literature, 36(4), 1947-1982.

Coad, A. (2007). Firm Growth: A Survey. Max Planck Institute of Economics, Papers on Economics and Evolution No. 0703, Jena.

Daly, M.J., Campbell, M., Robson, G.B. \& Gallagher, C.C. (1991). Job Creation 1987-9: The Contributions of Large and Small Firms. Employment Gazette, February, 47-51.

Davis, S.J. \& Haltiwanger, J. (1999). Gross Job Flows. In O. Ashenfelter \& D. Card (Eds.), Handbook of Labor Economics, Volume 3 (pp. 2711-2805). Amsterdam: Elsevier.

Davis, S.J., Haltiwanger, J. \& Schuh, S. (1996a). Job Creation and Destruction. Cambridge, MA: MIT Press.

Davis, S.J., Haltiwanger, J. \& Schuh, S. (1996b). Small Business and Job Creation: Dissecting the Myth and Reassesing the Facts. Small Business Economics, 8(4), 297-315.

Davidsson, P. (2004). Researching Entrepreneurship. Heidelberg: Springer.

Davidsson, P. \& Delmar, F. (2003). Hunting for New Employment: The Role of High Growth Firms. In D.A. Kirby \& A. Watson (Eds), Small Firms and Economic Development in Developed and Transition Economies: A Reader (pp. 7-19). Hampshire, UK: Ashgate Publishing. 
Davidsson, P. \& Delmar, F. (2006). High-Growth Firms and Their Contribution to Employment: The Case of Sweden. In P. Davidsson, F. Delmar \& J. Wiklund (Eds.), Entrepreneurship and the Growth of Firms (pp. 156-178). Cheltenham, UK and Northampton, MA: Edward Elgar.

Davidsson, P. \& Henrekson, M. (2002). Determinants of the Prevalence of Start-ups and High-growth Firms. Small Business Economics, 19(2), 81-104.

Delmar, F., Davidsson, P. \& Gartner, W.B. (2003). Arriving at the High-growth Firm. Journal of Business Venturing, 18(2), 189-216.

Deschryvere, M. (2008). High-growth Firms and Job Creation in Finland. Discussion Paper No. 1144, Research Institute of the Finnish Economy (ETLA), Helsinki.

Fogel, K., Morck, R.K. \& Yeung, B. (2008). Big Business Stability and Economic Growth: Is What's Good for General Motors Good for America? Journal of Financial Economics, 89(1), 83-108.

Fritsch, M. (2008). How Does New Business Formation Affect Regional Development? Introduction to the Special Issue. Small Business Economics, 30(1), 1-14.

Fritsch, M. \& Mueller, P. (2004). Effects of New Business Formation on Regional Development over Time. Regional Studies, 38(3), 961-975.

Fritsch, M. \& Weyh, A. (2006). How Large are the Direct Employment Effects of New Businesses? An Empirical Investigation for West Germany. Small Business Economics, 26(2-3), 245-260.

Gallagher, C. \& Miller, P. (1991). New Fast-Growing Companies Create Jobs. Long Range Planning, 24(1), 96-101.

Halabisky, D., Dreessen, E. \& Parsley, C. (2006). Growth in Firms in Canada, 1985-1999. Journal of Small Business and Entrepreneurship, 19(3), 255-268.

Haltiwanger, J. \& Krizan, C. J. (1999), Small Business and Job Creation in the United States: The Role of New and Young Businesses. In Z.J. Acs, (Ed.), Are Small Firms Important? Their Role and Impact (pp. 79-97). Boston and Dordrecht: Kluwer Academic Publishers.

Haltiwanger, J. (2006). Entrepreneurship and Job Growth. Paper presented at the Kauffman Max Planck Conference on Entrepreneurship and Economic Growth, Munich.

Harrisson, B (1994). Lean and Mean: The Changing Landscape of Corporate Power in the Age of Flexibility. New York: Basic Books.

Henrekson, M. (2005). Entrepreneurship: A Weak Link in the Welfare State? Industrial and Corporate Change, 14(3), 447-467.

Henrekson, M. \& Jakobsson, U. (2005). The Swedish Model of Ownership and Corporate Control in Transition. In H. Huizinga \& L. Jonung (Eds.), Who Should Own Europe? (pp. 297-246) Cambridge, UK and New York: Cambridge University Press.

Henrekson, M. \& Johansson, D. (1999). Institutional Effects on the Evolution of the Size Distribution of Firms. Small Business Economics, 12(1), 11-23.

Henrekson, M. \& Johansson, D. (2009). Competencies and Institutions Fostering High-growth Firms. Foundations and Trends in Entrepreneurship, 5(1), 1-80.

Hoffman, A.N. \& Junge, M. (2006). Documenting Data on High-growth Firms and Entrepreneurs across 17 Countries. Mimeo, Fora, Copenhagen.

Johansson, D. (2005). The Turnover of Firms and Industry Growth. Small Business Economics, 24(5), 487-495.

Johansson, D. (2007). Sweden's Slowdown: The Impact of Interventionism on Entrepreneurship. In B. Powell (Ed.), Making Poor Nations Rich: Entrepreneurship and the Process of Economic Development (pp. 250-280). Palo Alto, CA: Stanford University Press.

Johnson, P. (1989a). Employment Change in the Small Establishment Sector in UK Manufacturing. Applied Economics, 21(2), 251-260.

Johnson, P. (1989b). Employment Change in Small Business. Results from a Follow up Survey. Report to the Department of Employment, Institute for Employment Research, University of Warwick. 
Johnson, P. (1991). Forecasting Small Business Employment Growth: Some Survey Findings for the UK. Paper presented to the $21^{\text {st }}$ European Small Business Seminar, Barcelona.

Jones, M. (1991). Employment Change in Small Firms: A Cohort Analysis from 1985, 1988 and 1991 Survey Findings. Paper presented to the $14^{\text {th }}$ Small Firms Policy and Research Conference, Blackpool.

Kirchhoff, B.A. (1994). Entrepreneurship and Dynamic Capitalism. Westport, CT: Praeger.

Kirchhoff, B.A. \& Greene, P.G. (1998). Understanding the Theoretical and Empirical Content of Critiques of U.S. Job Creation Research. Small Business Economics, 10(2), 153-169.

Klepper, S. (2002). Firm Survival and the Evolution of Oligopoly. RAND Journal of Economics, 33(1), 37-61.

Klepper, Steven and Simons, Kenneth L. (2005). Industry Shakeouts and Technological Change. International Journal of Industrial Organization, 23(1-2), 23-43.

Landström, H. (2005). Pioneers in Entrepreneurship and Small Business Research. Berlin: Springer.

Littunen, H. \& Tohmo, T. (2003). The High Growth in New Metal-Based Manufacturing and Business Service Firms in Finland. Small Business Economics, 21(2), 187-200.

Lotti, F., Santarelli, E., \& Vivarelli ,M. (2003). Does Gibrat's Law Hold Among Young, Small Firms? Journal of Evolutionary Economics, 13(3), 213-235.

Markman, G.D. \& Gartner, W.B. (2002). Is Extraordinary Growth Profitable: A Study of Inc. 500 High-growth Companies. Entrepreneurship Theory and Practice, 27(1), 65-75.

Morena, A.M. \& Casillas, J.C. (2007). High-growth SMEs versus Non-high-Growth SMEs: A Discriminant Analysis. Entrepreneurship and Regional Development, 19(1), 69-88.

NIERC (1988). Job Generation and Manufacturing Industry 1973-86. Belfast: Northern Ireland Economic Research Centre.

North, D. \& Smallbone, D. (1993). Employment Generation and Small Business Growth in Different Geographical Environments. Paper presented at the $16^{\text {th }}$ National Small Firms Policy and Research Policy Conference, Nottingham.

OECD (2002). High-growth SMEs and Employment. OECD: Paris.

OECD (2007). OECD Framework for the Evaluation of SME and Entrepreneurship Policies and Programmes. OECD: Paris.

Parker, S.C., Storey, D.J. \& van Witteloostuijn, A. (2005). What Happens to Gazelles? The Importance of Dynamic Management Strategy. Research Report, Entrepreneurship Research Series, Centre for Entrepreneurship, Durham Business School, Durham University, UK.

Picot, G. \& Dupuy, R. (1998). Job Creation by Company Size Class: The Magnitude, Concentration and Persistence of Job Gains and Losses in Canada. Small Business Economics, 10(2), 117-139.

Rajan, A. \& Pearson, R. (1986). UK Occupation and Employment Trends to 1990. London, U.K.: Institute of Manpower Studies and Butterworths' Press.

Reynolds, P. \& Miller, B. (1988). 1988 Minnesota New Firms Study: An Exploration of New Firms and their Economic Contributions. Center for Urban and Regional Affairs, Minneapolis.

Schreyer, P. (2000). High-growth Firms and Employment. OECD Science, Technology and Industry Working Papers, 2000/3, Paris.

Smallbone, D., Leigh, R. \& North, D. (1993). The Growth and Survival of Mature Manufacturing SMEs in the 1980s: An Urban and Rural Comparison. In J. Curran \& D.J. Storey (Eds.), Small Firms in Urban and Rural Locations (pp. 79-131). London and New York: Routledge.

Stam, E. (2005). The Geography of Gazelles in the Netherlands. Tijdschrift voor Economische en Sociale Geografie, 96(1), 121-127.

Storey, D.J. (1985). Manufacturing Change in Northern England 1965-1978: The Role of Small Businesses. In D.J. Storey (Ed.), Small Firms in Regional Economic Development: Britain, Ireland and the United States (pp. 6-42). Cambridge, UK: Cambridge University Press.

Storey, D.J. (1994). Understanding the Small Business Sector. London: Routledge. 
Storey, D.J. (1995). Symposium on Harrisson's "Lean and Mean": A Job Generation Perspective. Small Business Economics, 7(5), 337-340.

Storey, D.J. (1996, 1997, 1998, 1999). The Ten Percenters. Fast Growing SMEs in Great Britain. First, Second, Third and Fourth Report. London: Deloitte \& Touche International.

Storey, D.J., Keasey, K., Watson, R. \& Wynarczyk, P. (1987). The Performance of Small Firms: Profits, Jobs and Failures. London: Croom Helm.

Sutton, J. (1997). Gibrat's Legacy. Journal of Economic Literature, 35(1), 40-59.

Van Praag, M.C. \& Versloot, P.H. (2008). The Economic Benefits and Costs of Entrepreneurship: A Review of the Research. Foundations and Trends in Entrepreneurship Research, 4(2), 65-154.

Woods, A., Blackburn, R. \& Curran, J. (1993). A Longitudinal Study of Small Enterprises in the Service Sector. Small Business Research Centre, Kingston University and Department of Management Studies, Brunel University. 
Table 1 Summary of studies on Gazelles as job contributors.

\begin{tabular}{|c|c|c|c|c|c|c|c|c|c|c|}
\hline Study & $\begin{array}{l}\text { Measure of } \\
\text { employment } \\
\text { growth }\end{array}$ & $\begin{array}{l}\text { Process of } \\
\text { growth: total, } \\
\text { organic or } \\
\text { acquired } \\
\end{array}$ & $\begin{array}{l}\text { Regularity of } \\
\text { growth }\end{array}$ & Period & Gazelle definition & \begin{tabular}{|l|}
$\begin{array}{l}\text { Country or } \\
\text { countries }\end{array}$ \\
\end{tabular} & $\begin{array}{l}\text { Industry or } \\
\text { industries }\end{array}$ & $\begin{array}{l}\text { Firm type or } \\
\text { firm types }\end{array}$ & $\begin{array}{l}\text { Data source or } \\
\text { data sources }\end{array}$ & Main result \\
\hline $\begin{array}{l}\text { Birch and } \\
\text { Medoff (1994) }\end{array}$ & $\begin{array}{l}\text { Absolute } \\
\text { employment }\end{array}$ & Total & Annual & $1988-92$ & \begin{tabular}{|l|} 
A business \\
establishment $\geq$ \\
$20 \%$ sales growth \\
each year over the \\
interval, and base- \\
year revenue $\geq$ \\
$\$ 100,000$
\end{tabular} & U.S. & All & Ongoing firms & Dun \& Bradstreet & $\begin{array}{l}\text { A small number } \\
(4 \%) \text { of ongoing } \\
\text { firms create a } \\
\text { disproportionately } \\
\text { large share of all } \\
\text { new jobs in the U.S. } \\
(60 \%)\end{array}$ \\
\hline $\begin{array}{l}\text { Kirchhoff } \\
\text { (1994) }\end{array}$ & $\begin{array}{l}\text { Relative } \\
\text { employment }\end{array}$ & Total & $\begin{array}{l}\text { Between start and } \\
\text { final year }\end{array}$ & $\begin{array}{l}1977-78 \text { to } \\
1984\end{array}$ & $\begin{array}{l}\text { The } 10 \% \text { fastest } \\
\text { growing firms in } \\
\text { the investigated } \\
\text { population }\end{array}$ & U.S. & $\begin{array}{l}\text { Nonagricultural, } \\
\text { private sector }\end{array}$ & \begin{tabular}{|l|} 
New single \\
establishments \\
with $<500$ \\
employees \\
established in \\
1977 and 1978 \\
\end{tabular} & $\begin{array}{l}\text { Small Business } \\
\text { Data Base (SBDB) }\end{array}$ & $\begin{array}{l}4 \% \text { of firms produce } \\
75 \% \text { of employment } \\
\text { in studied cohorts }\end{array}$ \\
\hline Storey (1994) & $\begin{array}{l}\text { Survey of } 14 \\
\text { studies }\end{array}$ & Total & Different & Different & Different & $\begin{array}{l}\text { The U.K., } \\
\text { except for one } \\
\text { U.S. study }\end{array}$ & $\begin{array}{l}\text { Mainly } \\
\text { manufacturing }\end{array}$ & Different & Different & $\begin{array}{l}\text { Approximately } 4 \% \\
\text { of firms create } \\
\text { approximately half } \\
\text { the new jobs in } \\
\text { studied firms }\end{array}$ \\
\hline $\begin{array}{l}\text { Birch et al. } \\
\text { (1995) }\end{array}$ & $\begin{array}{l}\text { Absolute } \\
\text { employment }\end{array}$ & Total & Annual & $\begin{array}{l}1990-94 \\
\end{array}$ & \begin{tabular}{|l|} 
A business \\
establishment $\geq$ \\
$20 \%$ sales growth \\
each year over the \\
interval, and base- \\
year revenue $\geq$ \\
USD 100,000 \\
\end{tabular} & U.S. & All & Continuing firms & Dun \& Bradstreet & $\begin{array}{l}\text { Gazelles account for } \\
\text { all new jobs in the } \\
\text { whole economy }\end{array}$ \\
\hline $\begin{array}{l}\text { Picot and } \\
\text { Dupuy (1998) }\end{array}$ & $\begin{array}{l}\text { Absolute and } \\
\text { relative } \\
\text { employment }\end{array}$ & Total & $\begin{array}{l}\text { Annual and } \\
\text { between start and } \\
\text { final year }\end{array}$ & $\begin{array}{l}1978-92 \text { and } \\
1983-86\end{array}$ & $\begin{array}{l}\text { Different high- } \\
\text { growth thresholds }\end{array}$ & Canada & $\begin{array}{l}\text { Commercial } \\
\text { sector }\end{array}$ & $\begin{array}{l}\text { All and } \\
\text { continuing firms }\end{array}$ & $\begin{array}{l}\text { Longitudinal } \\
\text { Employment } \\
\text { Analysis Program } \\
\text { (LEAP) }\end{array}$ & $\begin{array}{l}\text { Job generation } \\
\text { concentrated to a } \\
\text { few fast-growing } \\
\text { firms in the sample }\end{array}$ \\
\hline
\end{tabular}


Table 1 Continued.

\begin{tabular}{|c|c|c|c|c|c|c|c|c|c|c|}
\hline Study & $\begin{array}{l}\text { Measure of } \\
\text { employment } \\
\text { growth }\end{array}$ & $\begin{array}{l}\text { Process of } \\
\text { growth: total, } \\
\text { organic or } \\
\text { acquired } \\
\end{array}$ & $\begin{array}{l}\begin{array}{l}\text { Regularity of } \\
\text { growth }\end{array} \\
\end{array}$ & Period & Gazelle definition & $\begin{array}{l}\text { Country or } \\
\text { countries }\end{array}$ & $\begin{array}{l}\text { Industry or } \\
\text { industries }\end{array}$ & $\begin{array}{l}\text { Firm type or } \\
\text { firm types }\end{array}$ & $\begin{array}{l}\text { Data source or data } \\
\text { sources }\end{array}$ & Main result \\
\hline $\begin{array}{l}\text { Autio et al. } \\
(2000)\end{array}$ & $\begin{array}{l}\text { Absolute } \\
\text { employment }\end{array}$ & Total & Annual & 1994-97 & $\begin{array}{l}\geq 50 \% \text { sales growth } \\
\text { three consecutive years } \\
1994-97 \text { and } \geq \text { FIM } 1 \\
\text { million in sales at end } \\
\text { of period. }\end{array}$ & Finland & All & $\begin{array}{l}\text { Independent } \\
\text { continuing } \\
\text { single } \\
\text { establishments }\end{array}$ & Statistics Finland & $\begin{array}{l}\text { High-growth firms } \\
\text { increased their } \\
\text { employment by more } \\
\text { than } 400 \%\end{array}$ \\
\hline $\begin{array}{l}\text { Brüderl and } \\
\text { Prisendörfer } \\
(2000)\end{array}$ & $\begin{array}{l}\text { Absolute and } \\
\text { relative } \\
\text { employment }\end{array}$ & Total & $\begin{array}{l}\text { Between start } \\
\text { and final year }\end{array}$ & \begin{tabular}{|l|}
$1985-86$ \\
to 1990
\end{tabular} & $\begin{array}{l}\text { Surviving firms, } \\
\text { growing more than } \\
100 \% \text { and growing by } \\
\geq 5 \text { employees in the } \\
\text { studied period }\end{array}$ & \begin{tabular}{|l} 
Germany, \\
Upper Bavaria
\end{tabular} & $\begin{array}{l}\text { All, but crafts, agri- } \\
\text { cultural businesses, } \\
\text { physicians, } \\
\text { architects and } \\
\text { lawyers }\end{array}$ & $\begin{array}{l}\text { New firms } \\
\text { founded in } \\
1985-86\end{array}$ & $\begin{array}{l}\text { The Munich Founder } \\
\text { Study }\end{array}$ & $\begin{array}{l}\text { A small number (4\%) } \\
\text { of rapidly growing } \\
\text { firms are crcucial for } \\
\text { job generation }\end{array}$ \\
\hline $\begin{array}{l}\text { Schreyer (2000), } \\
\text { France }\end{array}$ & $\begin{array}{l}{ }^{\mathrm{a}} \text { Composite } \\
\text { index }\end{array}$ & Total & $\begin{array}{l}\text { Between start } \\
\text { and final year }\end{array}$ & 1985-94 & $\begin{array}{l}\text { The } 10 \% \text { fastest } \\
\text { growing firms in the } \\
\text { investigated population }\end{array}$ & France & $\begin{array}{l}\text { Manufacturing and } \\
\text { other non-service } \\
\text { industries like } \\
\text { mining }\end{array}$ & $\begin{array}{l}{ }^{b} \text { Permanent } \\
\text { firms employing } \\
\geq 20 \text { people at } \\
\text { the beginning of } \\
\text { the period }\end{array}$ & $\begin{array}{l}\text { Annual Business } \\
\text { Survey of the } \\
\text { Statistics Survice } \\
\text { (SESSI) }\end{array}$ & $\begin{array}{l}\text { High-growth firms } \\
\text { contribute a } \\
\text { disproportionately } \\
\text { large part of job } \\
\text { creation among } \\
\text { studied firms }\end{array}$ \\
\hline $\begin{array}{l}\text { Schreyer (2000), } \\
\text { Canada }\end{array}$ & $\begin{array}{l}{ }^{\mathrm{a}} \text { Composite } \\
\text { index }\end{array}$ & Total & $\begin{array}{l}\text { Between start } \\
\text { and final year }\end{array}$ & 1990-96 & $\begin{array}{l}\text { The } 5 \% \text { fastest } \\
\text { growing firms in the } \\
\text { investigated population }\end{array}$ & Quebec & Manufacturing & $\begin{array}{l}{ }^{b} \text { Permanent } \\
\text { firms employing } \\
\geq 20 \text { people at } \\
\text { the beginning of } \\
\text { the period }\end{array}$ & $\begin{array}{l}\text { The Scott data bank } \\
\text { and the Quebec } \\
\text { Industrial Research } \\
\text { Centre (CRIQ) data }\end{array}$ & $\begin{array}{l}\text { High-growth firms } \\
\text { contribute a } \\
\text { disproportionately } \\
\text { large part of job } \\
\text { creation among } \\
\text { studied firms }\end{array}$ \\
\hline $\begin{array}{l}\text { Schreyer (2000), } \\
\text { Italy }\end{array}$ & $\begin{array}{l}{ }^{\mathrm{a}} \text { Composite } \\
\text { index }\end{array}$ & Total & $\begin{array}{l}\text { Between start } \\
\text { and final year }\end{array}$ & \begin{tabular}{|l|}
$1990-95$ \\
\end{tabular} & $\begin{array}{l}\text { The } 5 \% \text { fastest } \\
\text { growing firms in the } \\
\text { investigated population }\end{array}$ & Italy & $\begin{array}{l}\text { Manufacturing and } \\
\text { services }\end{array}$ & $\begin{array}{l}{ }^{b} \text { Permanent } \\
\text { firms employing } \\
>20 \text { people at } \\
\text { the beginning of } \\
\text { the period }\end{array}$ & $\begin{array}{l}\text { The Excelsior } \\
\text { database }\end{array}$ & $\begin{array}{l}\text { High-growth firms } \\
\text { account for a } \\
\text { disproportionately } \\
\text { large part of job } \\
\text { creation among } \\
\text { studied firms }\end{array}$ \\
\hline $\begin{array}{l}\text { Schreyer (2000), } \\
\text { Netherlands }\end{array}$ & $\begin{array}{l}{ }^{\mathrm{a}} \text { Composite } \\
\text { index }\end{array}$ & Total & $\begin{array}{l}\text { Between start } \\
\text { and final year }\end{array}$ & \begin{tabular}{|l|}
$1989-94$ \\
\end{tabular} & $\begin{array}{l}\text { The } 5 \% \text { fastest growing } \\
\text { firms in the } \\
\text { investigated population }\end{array}$ & Netherlands & Manufacturing & $\begin{array}{l}{ }^{\mathrm{b}} \text { Permanent } \\
\text { firms employing } \\
\geq 20 \text { people at } \\
\text { the end of the } \\
\text { period }\end{array}$ & \begin{tabular}{|l|} 
The Review and \\
Analysis of \\
Companies in \\
Holland (REACH) \\
database \\
\end{tabular} & \begin{tabular}{|l|} 
High-growth firms \\
contribute a dispro- \\
portionately large part \\
of job creation among \\
studied firms \\
\end{tabular} \\
\hline
\end{tabular}


Table 1 Continued.

\begin{tabular}{|c|c|c|c|c|c|c|c|c|c|c|}
\hline Study & \begin{tabular}{|l} 
Measure of \\
employment \\
growth
\end{tabular} & $\begin{array}{l}\text { Process of } \\
\text { growth: total, } \\
\text { organic or } \\
\text { acquired } \\
\end{array}$ & \begin{tabular}{|l}
$\begin{array}{l}\text { Regularity of } \\
\text { growth }\end{array}$ \\
\end{tabular} & Period & \begin{tabular}{|l}
$\begin{array}{l}\text { Gazelle } \\
\text { definition }\end{array}$ \\
\end{tabular} & $\begin{array}{l}\text { Country or } \\
\text { countries }\end{array}$ & \begin{tabular}{|l} 
Industry or \\
industries
\end{tabular} & $\begin{array}{l}\text { Firm type or } \\
\text { firm types }\end{array}$ & \begin{tabular}{|l|}
$\begin{array}{l}\text { Data source or data } \\
\text { sources }\end{array}$ \\
\end{tabular} & Main result \\
\hline $\begin{array}{l}\text { Schreyer (2000), } \\
\text { Spain }\end{array}$ & ${ }^{\mathrm{a}}$ Composite index & Total & $\begin{array}{l}\text { Between start and } \\
\text { final year }\end{array}$ & 1990-94 & $\begin{array}{l}\text { The } 10 \% \text { fastest } \\
\text { growing firms in } \\
\text { the investigated } \\
\text { population }\end{array}$ & Spain & $\begin{array}{l}\text { Manufacturing and } \\
\text { services }\end{array}$ & $\begin{array}{l}{ }^{\mathrm{b}} \text { Permanent } \\
\text { firms } \\
\text { employing } \geq 10 \\
\text { people at the } \\
\text { end of the } \\
\text { period }\end{array}$ & $\begin{array}{l}\text { The Business } \\
\text { strategy survey } \\
\text { (ESEE) }\end{array}$ & $\begin{array}{l}\text { High-growth } \\
\text { firms contribute a } \\
\text { disproportionately } \\
\text { large part of job } \\
\text { creation among } \\
\text { studied firms }\end{array}$ \\
\hline $\begin{array}{l}\text { Schreyer (2000), } \\
\text { Germany }\end{array}$ & $\begin{array}{l}{ }^{c} \text { Logarithmic } \\
\text { AARG }\end{array}$ & Total & $\begin{array}{l}\text { Between start and } \\
\text { final year }\end{array}$ & $1992-95$ & $\begin{array}{l}\text { The } 10 \% \text { fastest } \\
\text { growing firms in } \\
\text { the investigated } \\
\text { population }\end{array}$ & West Germany & $\begin{array}{l}\text { The entire private } \\
\text { sector }\end{array}$ & $\begin{array}{l}\text { bermanent } \\
\text { firms }\end{array}$ & \begin{tabular}{|l|} 
Mannheimer \\
Unternehmens panel \\
(MUP) and Mann- \\
heimer Innovation \\
Panel (MIP)
\end{tabular} & \begin{tabular}{|l|} 
High-growth \\
firms contribute a \\
disproportionately \\
large part of job \\
creation among \\
studied firms \\
\end{tabular} \\
\hline $\begin{array}{l}\text { 'Sweden in } \\
\text { Schreyer (2000); } \\
\text { Davidsson and } \\
\text { Delmar (2003, } \\
\text { 2006); Delmar et } \\
\text { al. (2003) }\end{array}$ & \begin{tabular}{|l} 
Absolute \\
employment
\end{tabular} & $\begin{array}{l}\text { Total, organic and } \\
\text { acquired }\end{array}$ & Annual & $1987-96$ & $\begin{array}{l}\text { The } 10 \% \text { fastest } \\
\text { growing firms in } \\
\text { the investigated } \\
\text { population }\end{array}$ & Sweden & \begin{tabular}{|l} 
Private \\
commercially \\
active firms
\end{tabular} & $\begin{array}{l}\text { All firms } \\
\text { employing } \geq 20 \\
\text { people by } 1996\end{array}$ & $\begin{array}{l}\text { Statistics Sweden, } \\
\text { census }\end{array}$ & $\begin{array}{l}\text { Gazelles created } \\
\text { all new jobs in the } \\
\text { investigated } \\
\text { population }\end{array}$ \\
\hline $\begin{array}{l}\text { Littunen and } \\
\text { Tohmo (2003) }\end{array}$ & $\begin{array}{l}\text { Absolute } \\
\text { employment }\end{array}$ & Total & $\begin{array}{l}\text { Between start and } \\
\text { final year }\end{array}$ & 1990-97 & 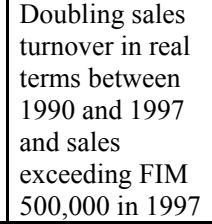 & Finland & $\begin{array}{l}\text { Metal-based } \\
\text { manufacturing and } \\
\text { business service } \\
\text { firms }\end{array}$ & \begin{tabular}{|l} 
Firms \\
established in \\
1990
\end{tabular} & Sample & $\begin{array}{l}\text { High-growth } \\
\text { firms accounted } \\
\text { for all jobs } \\
\text { created in the } \\
\text { investigated } \\
\text { population }\end{array}$ \\
\hline $\begin{array}{l}\text { Fritsch and } \\
\text { Weyh (2006) }\end{array}$ & \begin{tabular}{|l|} 
Absolute \\
employment
\end{tabular} & Total & \begin{tabular}{|l|} 
Annual and \\
between start and \\
final year
\end{tabular} & 1984-2002 & $\begin{array}{l}\text { Employment } \\
\text { shares of the 1, } \\
5,10 \text { and } 25 \% \\
\text { largest firms in } \\
\text { different cohorts }\end{array}$ & West Germany & $\begin{array}{l}\text { All private sector } \\
\text { industries }\end{array}$ & $\begin{array}{l}\text { Start-ups dur- } \\
\text { ing the studied } \\
\text { period with } \geq 1 \\
\text { employee and } \\
\text { with } \leq 20 \text { em- } \\
\text { ployees in the } \\
\text { initial year }\end{array}$ & \begin{tabular}{|l|} 
German Social \\
Insurance Statistics, \\
Census
\end{tabular} & $\begin{array}{l}\text { A small } \\
\text { proportion of the } \\
\text { firms dominate } \\
\text { job creation in the } \\
\text { studied cohort }\end{array}$ \\
\hline $\begin{array}{l}\text { Halabisky et al. } \\
(2006)\end{array}$ & \begin{tabular}{|l}
$\begin{array}{l}\text { Absolute } \\
\text { employment }\end{array}$ \\
\end{tabular} & Total & $\begin{array}{l}\text { Between start and } \\
\text { final year }\end{array}$ & 1985-1999 & $\begin{array}{l}\text { Firms growing } \\
\text { by more than } \\
50 \% \text { between } \\
1985 \text { and } 1999\end{array}$ & Canada & $\begin{array}{l}\text { All, except health, } \\
\text { education and } \\
\text { government }\end{array}$ & $\begin{array}{l}\text { All continuing } \\
\text { employer firms }\end{array}$ & $\begin{array}{l}\text { The Longitudinal } \\
\text { Employment Analy- } \\
\text { sis Program (LEAP) } \\
\text { and the Small Area } \\
\text { File (SAF) }\end{array}$ & $\begin{array}{l}\text { Fast growing } \\
\text { firms generated } \\
\text { the bulk of new } \\
\text { jobs in the private } \\
\text { sector. }\end{array}$ \\
\hline
\end{tabular}


Table 1 Continued.

\begin{tabular}{|c|c|c|c|c|c|c|c|c|c|c|}
\hline Study & \begin{tabular}{|l} 
Measure of \\
employment \\
growth
\end{tabular} & $\begin{array}{l}\text { Process of } \\
\text { growth: total, } \\
\text { organic or } \\
\text { acquired } \\
\end{array}$ & $\begin{array}{l}\text { Regularity of } \\
\text { growth }\end{array}$ & Period & Gazelle definition & $\begin{array}{l}\text { Country or } \\
\text { countries }\end{array}$ & $\begin{array}{l}\text { Industry or } \\
\text { industries }\end{array}$ & $\begin{array}{l}\text { Firm type or } \\
\text { firm types }\end{array}$ & \begin{tabular}{|l|} 
Data source or \\
data sources
\end{tabular} & Main result \\
\hline $\begin{array}{l}\text { Acs and } \\
\text { Mueller (2008) }\end{array}$ & $\begin{array}{l}\text { Relative } \\
\text { employment }\end{array}$ & Total & $\begin{array}{l}\text { Regional } \\
\text { employment } \\
\text { change over } 3 \\
\text { years }\end{array}$ & 1990-2003 & $\begin{array}{l}\text { New rapidly } \\
\text { growing firms } \\
\text { with } 20-499 \\
\text { employees in the } \\
\text { year of entry }\end{array}$ & $\begin{array}{l}320 \text { Metropolitan } \\
\text { Statistical Areas in } \\
\text { the U.S. }\end{array}$ & $\begin{array}{l}\text { Every U.S. } \\
\text { private sector } \\
\text { (non-farm) } \\
\text { business with } \\
\text { employees }\end{array}$ & $\begin{array}{l}\text { New } \\
\text { establishments }\end{array}$ & $\begin{array}{l}\text { Longitudinal } \\
\text { Establishment and } \\
\text { Enterprise Micro- } \\
\text { data (LEEM) and } \\
\text { the Current Em- } \\
\text { ployment Statistics } \\
\text { (CES) Survey } \\
\end{array}$ & $\begin{array}{l}\text { Gazelles in large } \\
\text { diversified } \\
\text { metropolitan } \\
\text { regions generate } \\
\text { long-term } \\
\text { employment } \\
\text { growth } \\
\end{array}$ \\
\hline $\begin{array}{l}\text { Acs et al. } \\
(2008)\end{array}$ & $\begin{array}{l}\text { Absolute } \\
\text { employment }\end{array}$ & Total & $\begin{array}{l}\text { Over 4-year } \\
\text { periods }\end{array}$ & 1994-2006 & $\begin{array}{l}\text { Enterprises that } \\
\text { double sales over } \\
\text { the 4-year period } \\
\text { between } 1998 \text { and } \\
2002 \text { and that have } \\
\text { an employment } \\
\text { growth quantifier } \\
\text { of at least } 2^{\mathrm{e}}\end{array}$ & U.S. & All & $\begin{array}{l}\text { Continuing } \\
\text { firms }\end{array}$ & \begin{tabular}{|l|} 
Business \\
Information \\
Tracking System \\
(BITS) and \\
Corporate Research \\
Board's American \\
Corporate \\
Statistical Library \\
(ACSL) \\
\end{tabular} & $\begin{array}{l}\text { High-impact firms } \\
(2-3 \% \text { of all firms) } \\
\text { create almost all net } \\
\text { jobs in the } \\
\text { economy }\end{array}$ \\
\hline $\begin{array}{l}\text { Deschryvere } \\
(2008)\end{array}$ & $\begin{array}{l}\text { Absolute and } \\
\text { relative } \\
\text { employment }\end{array}$ & $\begin{array}{l}\text { Total and } \\
\text { organic }\end{array}$ & Annual & 2003-2006 & $\begin{array}{l}\text { High growth firms } \\
\text { defined as firms } \\
\text { with an average } \\
\text { growth in em- } \\
\text { ployees }>20 \% \\
\text { cent p.a. over a 3- } \\
\text { year period, and } \\
\text { with } \geq 10 \text { em- } \\
\text { ployees initially } \\
\end{array}$ & Finland & All & $\begin{array}{l}\text { Continuing } \\
\text { firms }\end{array}$ & $\begin{array}{l}\text { Firm and } \\
\text { establishment data } \\
\text { from the Finnish } \\
\text { Business Register }\end{array}$ & $\begin{array}{l}\text { High growth firms } \\
(\approx 5 \% \text { of all firms) } \\
\text { generate more than } \\
\text { all net jobs in the } \\
\text { economy. Firm size } \\
\text { and organic growth } \\
\text { negatively related. }\end{array}$ \\
\hline
\end{tabular}

Note: ${ }^{\mathrm{a}}$ The composite index is calculated as $m=\left(x_{\mathrm{t} 1}-x_{\mathrm{t} 0}\right) *\left(x_{\mathrm{t} 1} / \mathrm{x}_{\mathrm{t} 0}\right)$, where $x_{\mathrm{t} 1}$ and $x_{\mathrm{t} 0}$ denote employment size by the end and the beginning of the period. ${ }^{\mathrm{b}} \mathrm{Permanent}$ firms are firms that existed during the entire period investigated. ${ }^{c} A A R G=$ Average annual rate of growth. ${ }^{\mathrm{d}}$ The Swedish study in Schreyer (2000), Davidsson and Delmar (2003, 2006) and Delmar et al. (2003) use similar data and draw similar conclusions. We therefore report on them jointly. ${ }^{\mathrm{e}}$ The employment growth quantifier is defined as the product of absolute and relative employment change over a 4-year period. 